\title{
THE DATA GAP
}

\section{Statistics on scientific investment and performance are lacking across the Muslim world. Declan Butler analyses the best of what is available.}

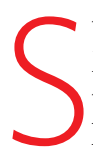

tretching from Indonesia to Morocco, and from Uganda to Kazakhstan, countries with large Muslim populations are home to some 1.3 billion people. The Islamic world encompasses remarkable diversity in political systems, geography, history, language and culture (see page 20). But science in these nations is weak, with spending on research and development far lower than the global average. This much is acknowledged to be true, but what of the details behind the broad picture?

The official statistics database of the Organization of the Islamic Conference (OIC) reveals information on each of the 57 OIC nations on everything from arable land per tractor to Internet users, but you won't find any data on research ${ }^{1}$. Science indicators for OIC countries are also scarce among data collected by the World Bank and United Nations agencies - largely a reflection of many of these countries' low level of interest in science.

To get a more detailed picture of how OIC countries measure up on science and technology, and of what patterns exist within OIC countries, Nature extracted science indicators

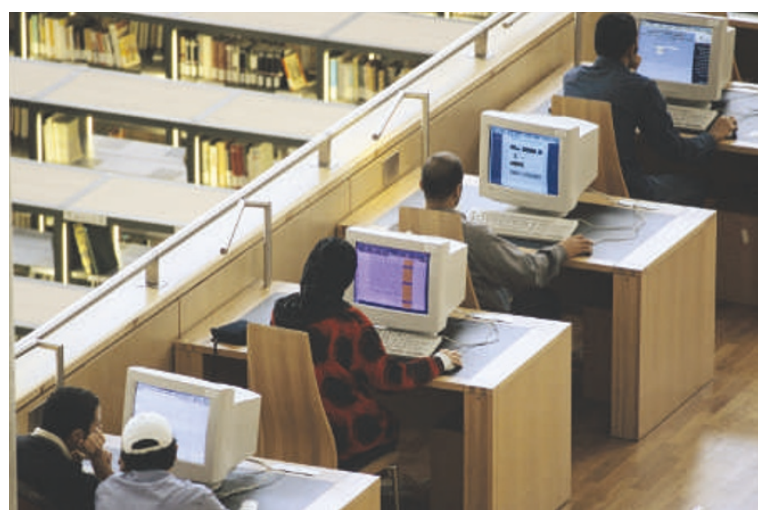

Can Islamic nations learn to capitalize on science and technology?

Although many OIC countries are among the world's poorest, with almost half being developing countries, their spending is consistently less compared with the national average across a range of income brackets. The exceptions are Malaysia and Turkey, whose spending is comparable to other moderately wealthy nations. Nowhere is the OIC deficit greater than in the oil-rich nations; Saudi Arabia and Kuwait, for example, spend less proportionately on research than the poorest OIC countries (see chart below, and page 28).

Part of the explanation lies in spending priorities. Many OIC countries, par-

from official sources and reanalysed them for the OIC group as a whole, creating an overall picture of science and technology indicators for OIC countries.

Recognized authorities such as UNESCO or the World Bank Development Indicators have few reliable data on science spending in most OIC countries. But combining these data for 20 OIC nations covering 1996-2003 gives the average annual spend on $R \& D$ as $0.34 \%$ of GDP, much lower than the global average over the same period of $2.36 \%$ (refs 2,3 ).

\section{R\&D SPENDING BY THE OIC COUNTRIES RELATIVE TO INCOME GROUP}

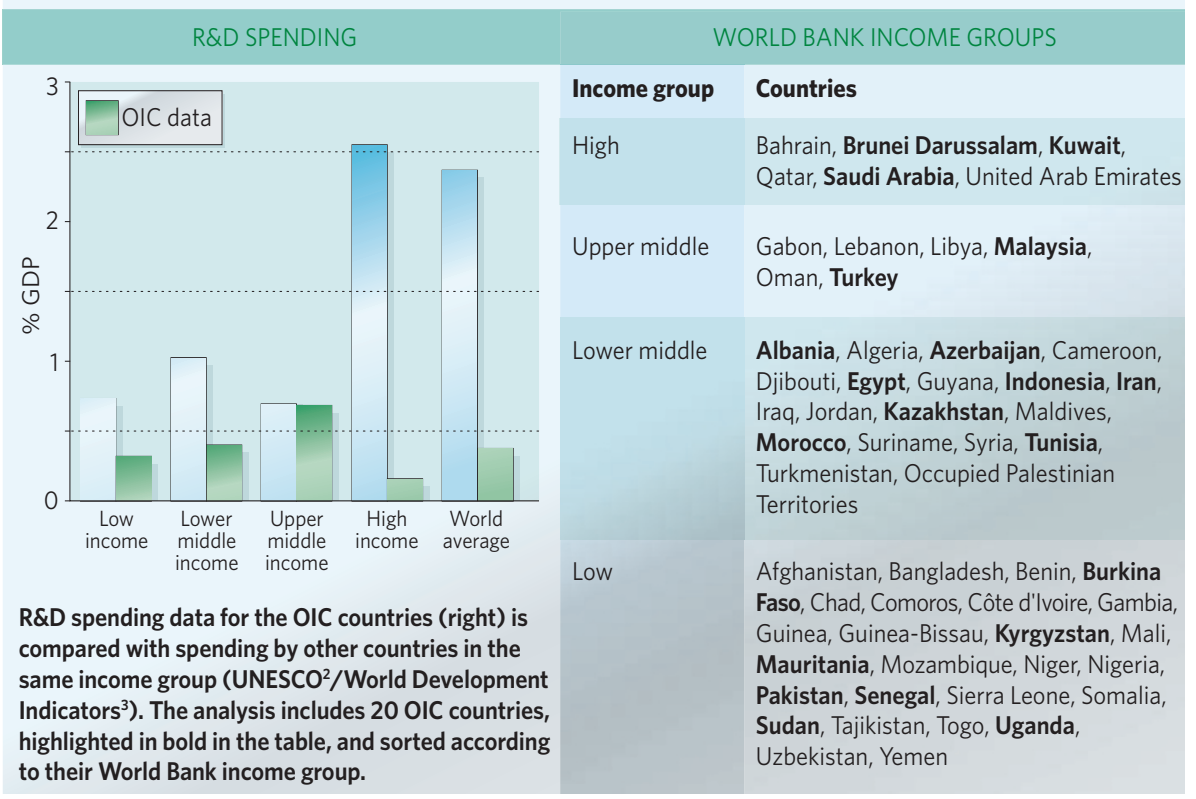

ticularly the richest, spend more on armaments than on science, education or health ${ }^{3}$. Six of the world's top ten military spenders as a share of public spending are OIC countries: Kuwait, Jordan, Saudi Arabia, Yemen, Syria and Oman (each spending above 7\% of GDP on arms in 2003). African OIC countries, in contrast, tend to spend proportionately less on the military.

\section{A tough lesson}

Although the science budgets of the OIC countries are all near the bottom of the world league, their spending on education is more variable. Malaysia, Saudi Arabia and Yemen's relative education budgets are among the world's highest. Morocco, Tunisia and Iran also spend respectable sums on education. All six were among the world's top 25 spenders on education in 2002 (ref. 3).

The OIC countries' performance in education also varies more widely, according to the World Bank's 'education index', suggesting that many have the human resources that could exploit greater investment in science and technology ${ }^{3}$.

But of the 20 poorest performers on this score, 15 are OIC countries, including many African nations, Bangladesh and Pakistan. The OIC countries' low investment in science and technology is also reflected in a poor scientific output, including low levels of scientific articles and numbers of researchers.

World Bank Development Indicators for 1996-2003 record numbers of researchers per million people for 19 OIC countries ${ }^{3}$. These OIC nations cluster at the bottom end of the global scale. The top global performers (Finland, 
Iceland, Sweden and Japan) all have above 5,000 researchers per million people. The highest scoring OIC country is Jordan, with 1,927 researchers per million people; the OIC average is 500 .

Of the 28 lowest producers of scientific articles, as recorded by the US National Science Foundation ${ }^{4}$, half are OIC countries. In 2003, the world average for production of articles per million inhabitants was 137 , whereas none of the 47 OIC countries for which there were data achieved production above 107 per million inhabitants ${ }^{4}$. The OIC average was just 13.

Moreover, over the past two decades the number of papers produced by 24 OIC nations has remained flat or declined, albeit with some striking exceptions ${ }^{4}$ (see chart, right). Turkey's publication rate per year has grown from around 500 in 1988 to more than 6,000 in 2003. The other rising star is Iran, which from a low base of less than 100 articles per year a decade ago now produces nearly 2,000. Both countries have eclipsed Egypt, previously the most prolific of all OIC states in scientific publishing, which grew only slowly between 1988 and 2003.

\section{Scientific divide}

The articles published by OIC countries show striking disciplinary and geographical differences $^{3}$. Health and social sciences get little attention except in south Asia and African countries. Chemistry and physics papers make up greater shares of total output in central Asian countries, life sciences in North Africa, Indonesia and Malaysia, as well as Saudi Arabia, and engineering predominates in most Middle Eastern and north African countries.

The OIC countries produce so few patents that they are invisible on a bar chart of comparison with other countries ${ }^{3}$. This lack of technological competitiveness translates into low rankings in terms of high-tech exports as a percentage of total exports - with one exception, Malaysia, which ranks fifth worldwide with $58 \%$ high-tech exports, alongside Singapore and the Philippines. Otherwise, Indonesia (14\%) and Morocco (11\%) are the only OIC countries with high-tech exports greater than $10 \%$.

Given such diversity, it is hard to identify trends across the Islamic world as a whole. But there are signs of hope when looking at the OIC's top and bottom performers.

Turkey, for example, is not rich in oil, but is the most scientifically successful of the Muslim states. Turkish intellectuals attribute this to the 1923 revolution, which led to the creation of a constitutionally secular state.

For decades, Turkey has aimed for membership of the European Union (EU); formal negotiations began last year. Negotiations require even closer structural alignment with EU

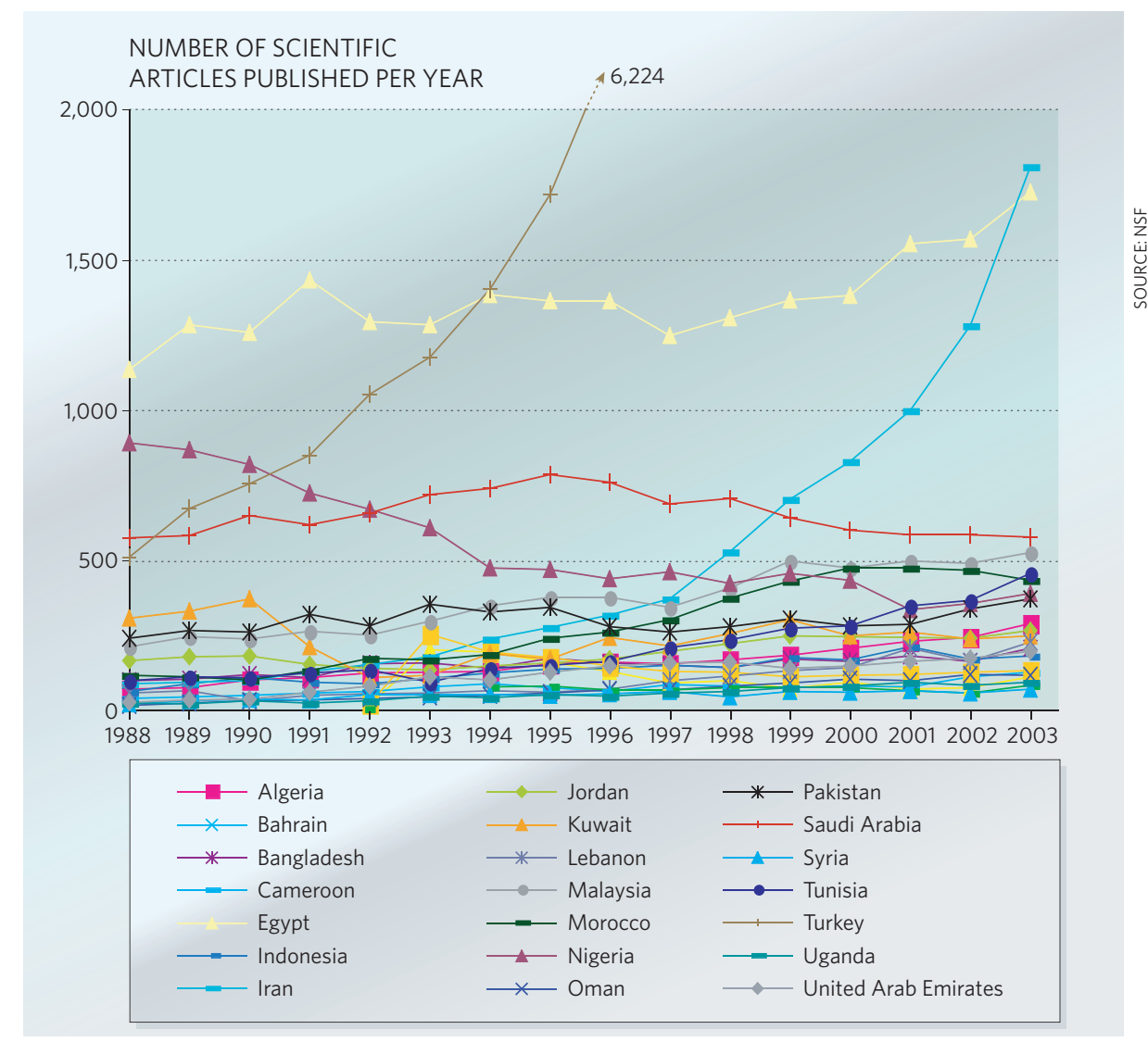

member states, and since 2003 science funding has more than trebled.

Modern Turkey grew from the ruins of the Ottoman empire. Mustafa Kemal Ataturk, Turkey's founder, was keen for his country to catch up with the West. Universities switched from using Arabic to the Roman alphabet, ensuring easier access to Western writings, and Ataturk initiated a nationwide campaign to raise literacy rates.

\section{Balancing act}

The Kemalist legacy has fostered Western-style scientific organizations and policies. But the insistence on removing religion from public life introduced restrictions of its own. For example, women are banned from wearing headscarves in government-funded universities - something that may have to change if Turkey joins the EU. Yet Turkey has respectable participation by women in academic life - higher than in some EU countries.

As for the bottom performers, sub-Saharan Africa accounts for 21 of the 57 OIC countries and, with the exception of Cameroon and Gabon, are among the poorest.

The ongoing economic recovery of subSaharan Africa is "one of the most remarkable stories of the past five years", according to the 2006 World Bank Development report ${ }^{3}$. The latest available data, for 2004, show five years of growth, after two decades of decline. Most was down to oil, but agriculture was also important. Among the OIC countries, Chad's economy grew more than $10 \%$ per year and Nigeria's $6 \%$. But overall economic levels remain poor, with growth rates usually far below the $7 \%$ minimum considered necessary to begin meeting the Millennium Development Goals. Several countries, including Côte d'Ivoire and Gabon, still show negative growth.

Not surprisingly, science is correspondingly weak, and although hard data are few, Islamic countries in sub-Saharan Africa have about 20 researchers and engineers per million people, compared with about 250 in Latin America. One potential bright spot is Nigeria, which announced in July that it is considering ploughing its oil revenues into a US\$5-billion endowment fund for science and technology, which would make it Africa's biggest science spender by far ${ }^{5}$.

If others follow where Turkey and Nigeria lead, these science indicators might look very different in ten years' time. As a first step, more OIC governments need to gather data on science, producing figures that are sufficiently reliable to appear in international statistics databases.

Declan Butler is a reporter for Nature based in Paris. Additional reporting by Ayla Arslan.

1. The Statistical, Economic and Social Research and Training Centre for Islamic Countries (SESRTCIC) www.sesrtcic. org/statistics/bycountry.php

2. UNESCO Statistics Division http://stats.uis.unesco.org/ ReportFolders/reportfolders.aspx

3. World Development Indicators (WDI), $2006 \mathrm{http}: / /$ devdata.worldbank.org/wdi2006/contents/index2.htm

4. National Science Board. Science and Engineering Indicators 2006. (National Science Foundation, Arlington, VA) www.nsf.gov/statistics/seind06/

5. Giles, J. Nature 442, 334 (2006).

See Editorial, page 1; Commentaries, pages 33, 35. 